Thematic

Section

Digital

transformation, intelligent

manufacturing

and supply chain

management 4.0

\title{
The impact of the collaborative robot on competitive priorities: case study of an automotive supplier
}

\author{
O impacto do robô colaborativo nas prioridades competitivas: \\ estudo de caso em um fornecedor automotivo
}

\author{
Marcos Vido ${ }^{1}$, Gabriela Scur ${ }^{1}$ [C, Alexandre Augusto Massote ${ }^{1}$, Fábio Lima ${ }^{1}$ \\ ${ }^{1}$ Centro Universitário FEI, Departamento de Engenharia de Produção, São Bernardo do Campo, SP, Brasil. E-mails: \\ marcosvido8@gmail.com; gabriela@fei.edu.br; massote@fei.edu.br; flima@fei.edu.br
}

How to cite: Vido, M., Scur, G., Massote, A. A., \& Lima, F. (2020). The impact of the collaborative robot on competitive priorities: case study of an automotive supplier. Gestão \& Produção, 27(4), e5358.

https://doi.org/10.1590/0104-530X5358-20

\begin{abstract}
The literature on operations strategies has extensively addressed the notion that competitive priorities and structural decisions should be aligned to create, develop, and maintain competitive advantages. However, the speed and scale of new manufacturing technologies are modifying an organization's strategies and manufacturing capabilities to address new market requirements, competition, and new entrants. Advances in robotics are poised to change the global business landscape and to support organizations in improving upon their operations strategies. Industrial robots usually help improve product quality and provide better work conditions to limit the use of resources, resulting in cost savings. One of the main trends in robotics is that of human-robot collaboration (HRC), which influences operations strategies and which can have a disruptive effect on business models and market structures. The aim of this paper is to explore and understand the relationship between the competitive priorities (quality, cost, flexibility, and delivery) of classical operations and the competitive advantage of adopting HRC for a Brazilian automotive parts supplier. The results indicate that the hybrid cell (U-shaped manufacturing cell) fully adheres to cost and dependability priorities and partially adheres to quality and flexibility priorities.
\end{abstract}

Keywords Competitive priorities; Competitive advantages; Collaborative operation; Collaborative robots; Industry 4.0

Resumo: A literatura sobre estratégia de operações tem extensivamente endereçado o conceito de prioridades competitivas e que decisões estruturais devem ser alinhadas para criar, desenvolver e manter as vantagens competitivas. Entretanto, a velocidade e escala de novas tecnologias de manufatura estão modificando as estratégias das organizações e as capacidades de manufatura para lidar com novos requisites de mercado, competição e novos entrantes. Os avanços na robótica estão preparados para mudar o cenário global dos negócios e suportar as organizações em melhorar suas estratégias de operações. Robôs industriais usualmente ajudam a melhorar a qualidade dos produtos e provêm melhor condições de trabalho para minimize o uso de recursos, resultando em economia de custos. Uma das principais tendências na robótica é a colaboração humano-robô (HRC), a qual influencia as estratégias de operações e pode ter um processo disruptivo nos modelos de negócios e nas estruturas de mercado. O objetivo principal desse artigo é explorar e entender a relação entre as prioridades competitivas

Received Feb. 22, 2019 - Accepted Apr. 23, 2019

Financial support: None.

This is an Open Access article distributed under the terms of the Creative Commons Attribution License, which permits unrestricted use, distribution, and reproduction in any medium, provided the original work is properly cited. 
(qualidade, custo, flexibilidade e entrega) das operações clássicas e a vantagem competitiva da adoção de CHR em um fornecedor brasileiro de autopeças. Os resultados indicam que a célula híbrida (célula de manufatura em forma de $U$ ) adere totalmente às prioridades de custo e confiabilidade e parcialmente adere às prioridades de qualidade e flexibilidade.

Palavras-chave: Prioridades competitivas, vantagens competitivas, operações colaborativas, robôs colaborativos, Indústria 4.0.

\section{Introduction}

Skinner (1969) was one of the first authors to elevate the manufacturing function to a strategic rather than merely tactical role. Subsequently, other authors (Hayes \& Wheelwright, 1984; Kim \& Arnold, 1996; Hill, 2000 and Slack \& Lewis, 2017) have supported and improved upon this approach. All of these authors argue that the manufacturing function can contribute to a firm's competitive advantage as long as it strengthens the implementation of a competitive strategy. Thus, Skinner (1969) describes a competitive advantage as the choices that operations managers make on key competitive priorities. Moreover, these choices constitute the expression of a firm's competitive strategy in terms that manufacturing laborers can understand (Díaz-Garrido et al., 2011). Since the seminal work of Skinner $(1969,1974)$ and with corroboration by Hayes \& Wheelwright (1984), it is understood that companies may compete in the marketplace by virtue of one or more of competitive priorities regarding quality, delivery, cost, and flexibility. Several authors and practitioners have adapted these priorities over the years and has identified other priorities such as those related to innovation, the time to market, lead times, and sustainability.

Recently, technologies related to Industry 4.0 have been treated as important competitive advantage tools and especially in strengthening competitive priorities. In addition, this is true not only in the business environment but also in the academy, which has witnessed an increase in the number of publications related to collaborative operations over last 10 years (Tsarouchi et al., 2016).

One of Industry 4.0's enabling technologies is that of advanced robotics or more specifically the collaborative robot (cobot). Cobots can support organizations that must use robots capable of operating under dynamic and unique production conditions based on principles of flexibility, customer demand, and product variation and quality (Vasic \& Billard, 2013). Automation and modernization cells using cobots bring productivity and efficiency gains to companies. In addition, collaborative robots allow for the customization of mass products, and the customer can in turn individually select from multiple product options (Kootbally, 2016).

Most previous works on the role of operations strategies in corporative strategies have focused on the "macro level" and on the hierarchical relationships between operations strategies and corporate and/or other functional strategies (Kim et al., 2014). Kim \& Arnold (1996) provided a different view of the operations strategy process by exploring internal consistencies between manufacturing's competitive priorities, objectives, and action plans based on a top-down assumption. However, given that the study relied on survey data, Kim \& Arnold (1996) were unable to examine how competitive priorities are translated into action plans and vice versa (Kim et al., 2014).

This paper seeks to address this gap in the literature by exploring how the use of collaborative robots impacts the competitive priorities of manufacturing firms. Our main objective is to identify the effect of the implementation of cobot technologies through collaborative operations on competitive priorities defined for the operations of one large 
Brazilian multinational auto parts manufacturer. The company implemented four collaborative cells under one U-shaped production cell until mid-2017.

The paper is structured into seven sections including this introduction. In sections 2 and 3 characteristics of fundamental operations strategies and of collaborative robots are examined in addition to the perspectives of Industry 4.0. Section 4 discusses the methodological procedures. This is followed by section 5 , which reports a case study on a Brazilian automotive supplier. Section 6 presents a discussion of the results, and section 7 presents the final considerations, including limitations and future research.

\section{Operations strategy}

Boyer \& McDermott (1999) argue that because operational decisions are made several times a day and for virtually every individual in an organization, a prerequisite to effective decision- making is for everyone to understand the organizational strategy employed. Based on this premise, it is accepted that a company's strategies for each operational function must be linked to the strategy of the associated business unit and in turn with the corporate strategy applied. Referring specifically with the operations function, Slack \& Lewis (2017) state that the basis of an operations strategy is to ensure that all operational competencies provide competitive advantages.

As noted above, Skinner (1969) was the first to recognize the potential strategic role of the manufacturing function as a competitive tool used by companies. Skinner (1974) reinforces this link by recognizing that because an operation cannot operate well at everything (there are trade-offs), a function should have a specific focus. Operationalizing these decisions (trade-offs) results in the development of focused factories (Maylor et al., 2015).

In searching for applications of an operations approach to project-based operations, Maylor et al. (2015) identify four additional means to support an organization's competitive advantages:

1. Strategic Intent: recognition of an opportunity-the difference between the company's current performance and its aspirations with deficiencies while providing input to change competitive priorities;

2. Focus: related to the relative weighting of required competitive priorities in terms of cost, quality, flexibility, and delivery for each market segment in which the company operates considering both market requirements and the company's current performance;

3. Fit: how well competitive priorities are aligned; and

4. Resource Configuration: how resources can be configured to meet competitive priorities.

According to Brown \& Bessant (2003) the operations strategy used is an important driver for achieving agility, one of the necessary capabilities of an operational strategy. According to the authors, agility can only be achieved by combining skills, technologies, know-how, processes, and even alliances and partnerships with other companies.

Based on a study performed by Brown \& Bessant (2003), Table 1 chronologically shows how different have authors approached the issue of operations strategies. 
Table 1. Definitions of manufacturing strategies.

\begin{tabular}{ll}
\hline Skinner (1969, 1974) & $\begin{array}{l}\text { The author provides information on the need to relate manufacturing } \\
\text { operations to strategic decisions made at the corporate level. }\end{array}$ \\
\hline Hayes \& Wheelwright (1984) & $\begin{array}{l}\text { The authors expand on Skinner's concept by delimiting the role of } \\
\text { manufacturing in business strategies. }\end{array}$ \\
\hline D'Aveni (1994) & $\begin{array}{l}\text { The author uses the term "hyper competition" to describe rapidly } \\
\text { growing competition that characterizes many industries. }\end{array}$ \\
\hline Schroeder et al. (1995) & The authors highlight the role of manufacturing strategies in gaining a \\
\hline Wathen (1995) & $\begin{array}{l}\text { competitive advantage through the pursuit of new process } \\
\text { technologies. }\end{array}$ \\
\hline Gagnon (1999) & $\begin{array}{l}\text { The authors point to improvements in manufacturing processes } \\
\text { through the adoption of techniques and procedures such as just in } \\
\text { time (JIT) and total quality management (TQM) methods. }\end{array}$ \\
\hline Keach et al. (2000) & $\begin{array}{l}\text { The authors point to the use of hybrid systems as a competitive } \\
\text { advantage. The work refers to a U-shaped cell. }\end{array}$ \\
\hline Other definitions & $\begin{array}{l}\text { The authors highlight the importance of not only changes in processes } \\
\text { and strategic priorities but also of the culture and beliefs of an } \\
\text { organization. }\end{array}$ \\
\hline Lien \& Rasch (2001) & $\begin{array}{l}\text { The authors describe ways to implement corporate missions through } \\
\text { operational plans. }\end{array}$ \\
\hline Lin \& Tseng (2016) &
\end{tabular}

In general, creating a competitive advantage depends on the extent to which manufacturing capabilities can leverage a variety of factors implied in manufacturing processes such as quality, continuous improvement, process technologies, and human skills (Brown \& Bessant, 2003). According to Lekurwale et al. (2015, p. 565) the "[...] manufacturing capability of a firm is given by the level of output generated by the production system employed, which in turn decides the competitiveness in the market."

More recently Slack \& Lewis (2017) have added that a company will gain a competitive edge over its competitors through its operations strategy when it is able to master new process technologies, achieve flexibility in its production capacities, minimize costs through improvement programs, and manage its supply chain.

Figure 1 shows the analytical framework of the operation strategy formation process based on above listed authors.

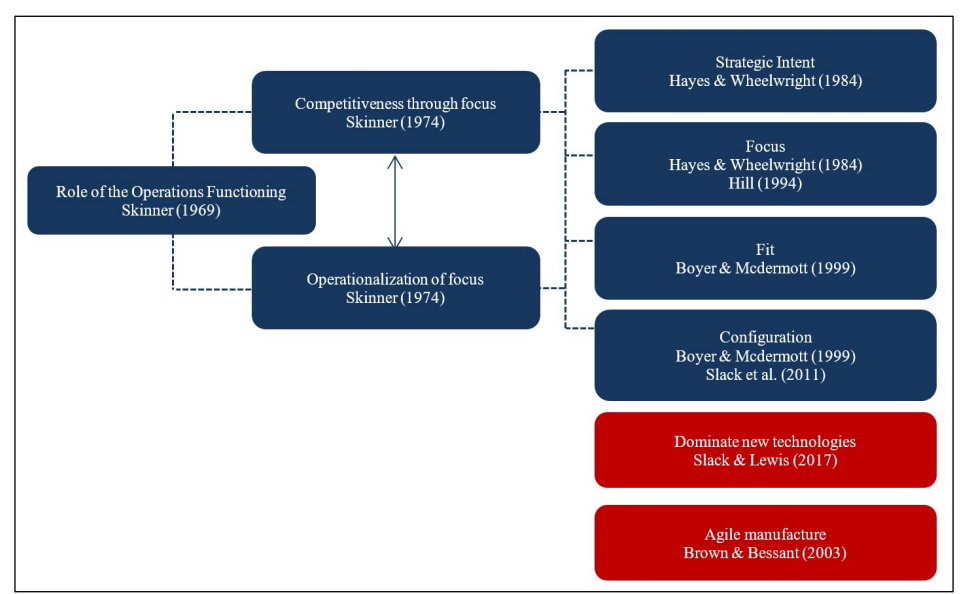

Figure 1. Progression of operations strategies. Source: Adapted from Maylor et al. (2015). 
Collaborative robotics can be used to achieve agile manufacturing (Brown \& Bessant, 2003) because this new process technology renders business operations more flexible (Slack \& Lewis, 2017).

\subsection{Competitive priorities}

Lin \& Tseng (2016) define competitive priorities as a propelling source of organizational change that transforms an organization's culture, processes, strategic priorities, and beliefs. The concept of competitive priority is important because it can lead organizations to achieve attainable goals when they implement corporate missions through operational plans by, for instance, establishing actions for the selection of manufacturing processes (Jitpaiboon et al., 2016).

There is consensus on the composition of main competitive priorities (cost, quality, flexibility, and delivery time) that form the content of a company's operations strategy (Skinner, 1969; Hayes \& Wheelwright, 1984). In addition to the four performance objectives defined by Skinner (1969) and Hayes \& Wheelwright (1984), other competitive priorities are presented in the literature, including those given by Slack \& Lewis (2017), who cite another performance objective_dependability. Jitpaiboon et al. (2016) analyze competitive priorities and show that they can be measured based on five performance criteria: low costs, quality, dependability, flexibility, and innovation.

Tan et al. (2007) argue that competitive priorities define the dimensions of operational capacities required for success. Moreover, competitive priorities relate to achieving competitiveness, developing capabilities, and enhancing competitive advantages (Lin \& Tseng, 2016).

According to Brown \& Bessant (2003), competitive priorities are important in creating a competitive advantage. Additionally, within a manufacturing environment, the generation of these competitive advantages is supported through the adoption of new process technologies, one of which is that of collaborative robotics. Due to competition and market demands, manufacturing must be able to respond quickly and effectively to customers' needs, which justifies automating a process to compete and innovate and to ensure flexibility and rapid product delivery (Brown \& Bessant, 2003; Groover, 2017). One tool of process automation is that of the hybrid system, which has been used as a competitive advantage in the industry for more than two decades (Lien \& Rasch, 2001).

\section{Industry 4.0}

Industry 4.0 describes the fourth Industrial Revolution occurring through the introduction of modern information and communication technologies into production (Qin et al., 2016). The term became the name of the Federal Government's high-tech strategy and was published for the first time in 2011, in Hannover (Su et al. 2017; Drath \& Horch, 2014). Industry 4.0 is a collective term referring to technologies and concepts of value chain organization. Within structured and modular intelligent factories, cyberphysical systems (CPSs) can monitor physical processes, create virtual copies of the physical world, and make decentralized decisions (Hermann et al., 2016). Industry 4.0 involves rapid and disruptive changes that encompass digital manufacturing, network communication, computing and automation technologies, and many other relevant areas (Fatorachian; Kazemi, 2018). Several digital technologies known as enablers 
such as those of advanced robotics, additive manufacturing, simulation, the Internet of things, and cloud computing, among others, help insert organizations into the industry 4.0 environment (Wang, 2015). Due to advances in robotics, industrial robots no longer operate in safety work cells but interact with human workers in hybrid systems through a new generation of light-weight and flexible robots that collaborate with humans more closely (Ore et al., 2016). In the context of Industry 4.0, as the manufacturing environment requires efficient robots to manage the dynamic conditions of production, the collaborative robot presents itself as a solution and as a link between humans and robots (Vasic \& Billard, 2013; Kootbally, 2016).

\subsection{Hybrid or collaborative systems}

Lotter (2012) defines a hybrid assembly system as one allowing for the easy assembly of components or various products in a combined automatic and manual workstation. The main premise of a hybrid system is to allow for human-machine collaboration by sharing a common workspace (Krüger et al., 2009). Lien \& Rasch (2001) and Heilala \& Voho (2001) define the hybrid system as a semi-automated workstation adopting a partially automated process. According to Heilala \& Voho (2001), a hybrid workstation consists of a combination of flexible workstations and different degrees of automation and includes manual workstations that manage materials automatically. Figure 2 illustrates three assembly approaches described by Lotter (2012) and Heilala \& Voho (2001) that are configured on the basis of expected production volumes and a required degree of system flexibility.

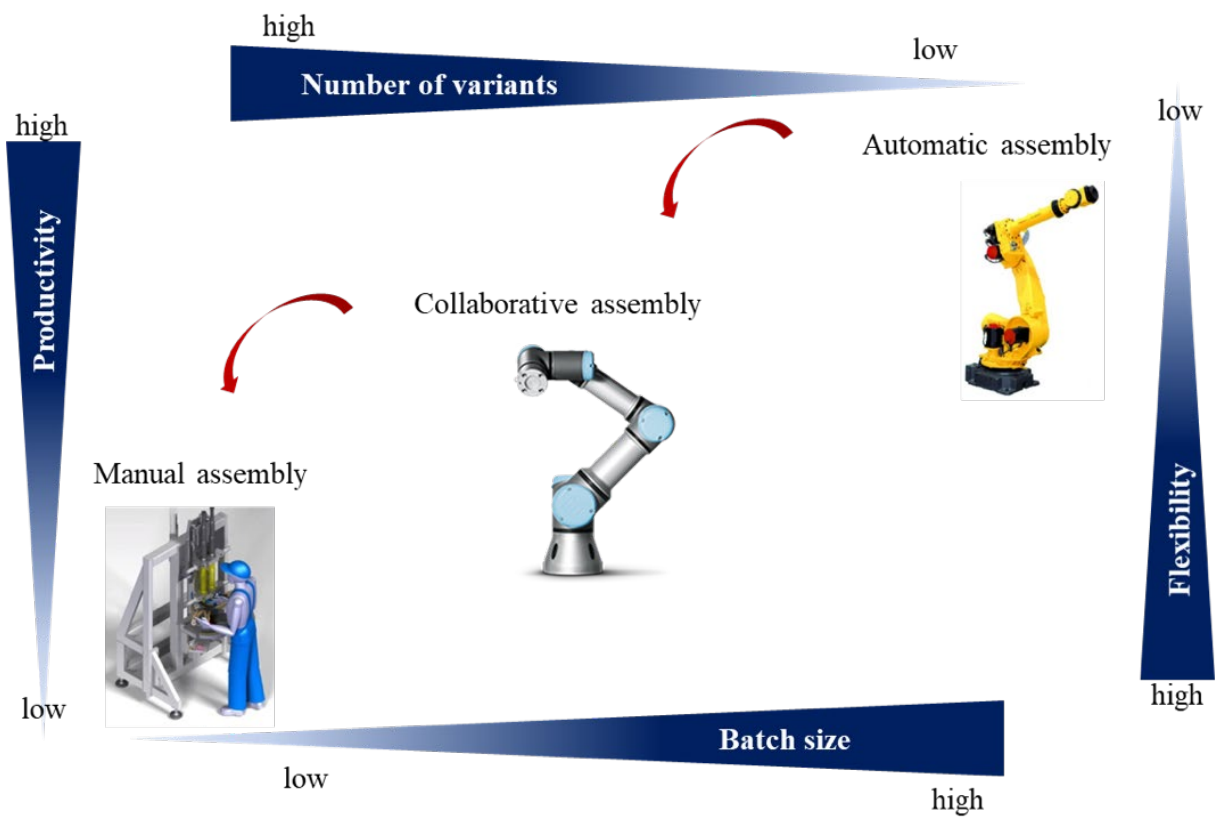

Figure 2. Types of assembly operations. Source: Adapted from Lotter (2012) and Heilala \& Voho (2001).

According to Heilala \& Voho (2001), a hybrid workstation includes a combination of flexible workstations adopting differing degrees of automation through manual 
workstations and supported by automated materials handling. According to the authors, a hybrid system is flexible; allows variation in workstation activities between robots and humans to meet demands; and is agile, quick to implement, ergonomic, and modular with a standard interface. When the process adopted is partially automated, the hybrid system is defined as a semiautomatic workstation (Lotter, 2012; Heilala \& Voho, 2001).

In a hybrid assembly line, the most time-consuming, critical, or ergonomically inefficient work phases must be automated (Heilala \& Voho, 2001).

Takata \& Hirano (2011) argue that industrial firms need to increase the efficiency of production systems to enhance their competitiveness. According to the authors, hybrid assembly systems evolve as solutions to this issue. Hybrid systems are competitive in executing medium volume assembly, in treating products with a standard basic structure, and in many tasks involving manual finishing (Lien \& Rasch, 2001). According to the authors, the use of hybrid or collaborative workstations in manufacturing presents advantages and disadvantages to the operator and machine.

Krüger et al. (2009) identify that automated assembly is free of breaks and fatigue and offers high levels of productivity in completing simple assembly tasks. According to the authors, the flexibility of automated systems such as robots is usually restricted due to considerable programming requirements and the limited skills needed to manage complex parts.

In regard to the operator, Krüger et al. (2009) claim that the operator provides unmatched motor sense skills of use for completing complex handling tasks and can adapt quickly to new process sequences but is restricted in strength and precision. In such a system, Takata \& Hirano (2011) state that humans and robots cooperate to perform assembly tasks. According to the authors, the system has the advantage of maximizing robot efficiency and human flexibility. An efficient way to use robotic and human capacities involves adopting an assembly system with a sequential division of tasks (Krüger et al., 2009). As described by the authors, the simple tasks suitable for robots are those requiring precision and repeatability. Complex tasks, which are often varied and add individual characteristics to assembled products, are performed and adjusted by the operators.

\subsubsection{Collaborative robots}

The development of the collaborative robotics market is driven mainly by applications for the manufacturing and assembly of electronic products, for new processes of the automotive industry, and for various types of manipulation operations used in small and medium-sized manufacturing companies (Bloss, 2016).

In recent years, the introduction of collaborative robotics as an enabling technology of Industry 4.0 has been a competitive priority of production (Lien \& Rasch, 2001). In the traditional scope of robotics, automation has turned to industrial applications with collaborative robotics requirements, representing a qualitative change in classic robot applications of manufacturing processes (Harper \& Virk, 2010).

The premise of the cobot design is to coexist and cooperate with humans in the same production environment. Cobots are designed such that operations allow robots to fulfill their manufacturing functions as independent productive units and to safely coexist alongside operators (Ibarguren et al., 2015, Krüger et al., 2009).

Cobots were initially developed in 1999 by professors Edward Colgate and Michael Peshkin at Northwestern University in Evanston, Illinois. A cobot is a robot designed to physically interact with humans in a shared workspace and to fill the gap between 
manual and automatic workstations (Peshkin et al., 2001). In such a system, humans and robots cooperate to perform assembly tasks and have the advantage of maximizing robot efficiency and human flexibility (Takata \& Hirano, 2011).

\subsubsection{Characteristics of a collaborative operation}

Tsarouchi et al. (2016) define a collaborative operation as adding value because it maintains favorable costs of production and applies the capacities of humans and robots. The collaborative operation improves quality indicators, capabilities, rework outcomes, flexibility and efficiency levels, and ergonomics, and the cycle time and space required are similar to those needed for manual work (Thiemermann, 2004; Krüger et al., 2009; Scholer, et al., 2015; Tsarouchi et al., 2016). Groover (2017) and Scholer et al. (2015) note that to capitalize on collaboration between humans and cobots in assembly tasks, it is necessary to apply the best qualities of both, such as precision in assembly, coordinating tasks, and agility in manipulating products, among others.

To achieve the highest level of physical collaboration between both, one must plan the division of labor (Thiemermann, 2004; Scholer et al., 2015). In addition, Charalambous et al. (2016) note that to ensure close connections between humans and cobots in assembly tasks and collaborative operations, their respective attributes must be applied. Table 2 illustrates the distribution of operator- and cobot-specific abilities and characteristics for combining the best attributes and achieving process efficiency.

Table 2. Skills distribution between cobots and operators.

\begin{tabular}{ll}
\hline Cobot & Operator \\
\hline$\checkmark$ Very repetitive & $\begin{array}{l}\checkmark \text { Tasks involving the use of strong cognitive } \\
\text { skills and reasoning }\end{array}$ \\
\hline$\checkmark$ Simple movements & $\checkmark$ Complex movements and dexterity \\
\hline$\checkmark$ Elementary visual verification & $\checkmark$ More complex visual verification \\
\hline$\checkmark$ Fatigue-proof, reliable, and straightforward & $\checkmark$ Elaborate decision making \\
$\begin{array}{ll}\text { decision making } & \text { Mainly standardized tasks involving different } \\
\text { variants and mixed models } & \text { mixed models, and unexpected events }\end{array}$ \\
\hline
\end{tabular}

Source: Scholer et al. (2015).

In addition to the attributes of the operator and cobot, Thiemermann (2004) and Scholer et al. (2015) note that the most appropriate process is planned for each of the partners during their interactions and according to their individual characteristics. According to the authors, collaboration between humans and robots in cooperative assembly tasks should adopt the qualities of both sides.

\section{Methodological procedures}

The objective of this paper is to understand the influence of the application of cobot technologies to the competitive priorities of Tier 1 operations. We adopt a qualitative approach in that the classification used based on its general objectives is exploratory and as our methodology we use a single case study. According to Eisenhardt (1989), 
the case study method is a research approach that focuses on understanding the dynamics of unique configurations. In addition to interviews, our case study applied other data collection methods, including a review of company files and documents and robot suppliers and direct observation and monitoring of cobot operations of a $U$ shaped production line and corresponding results, allowing for data triangulation and generating more reliable results (Yin, 2013).

Voss et al. (2002) state that a set of choices must be made when conducting a case study. One concerns the number of cases to be considered. Because a study of a single company may involve several different cases, the number of cases studied may differ from the number of companies considered.

The unit of analysis was a multinational Brazilian company hereinafter referred to as an auto company based in São Paulo. The auto company is one of the largest suppliers of sealing systems for main automakers and it exports its products to more than 40 countries. With global presence, the company operates two manufacturing units in Brazil in addition to factories in Argentina, the United States, Germany, Austria, China, and Hungary as well as technical and commercial offices in France, England, and Japan.

Operations and quality managers were selected based on their professional experience with collaborative operations in Brazil, and they were interviewed on site. The interviews were conducted in October and November 2017. Multiple researchers were involved to minimize potential investigator bias. Two authors of the paper conducted onsite visits and interviews together while the two other authors explored the data from the supplier's perspective. To comply with the "24-hours rule" (Eisenhardt \& Bourgeois, 1988), reports for each top manager were written immediately after each visit based on notes. The case write-ups were then used for field observations (Kim et al., 2014).

As our data collection instrument, we used transcripts taken from the semistructured interviews (Yin, 2013). The field interview protocol employed (Appendix A) explored research propositions constructed from the literature on competitive priorities and collaborative robotics.

\section{Within-case analysis}

In its operations management, the auto parts company applies the lean manufacturing program and automation systems to increase productivity levels. The company has also sought to adopt lean manufacturing practices to improve its manufacturing lines and to produce a larger variety of products with the least possible waste.

Under the principles of lean manufacturing and based on the auto company's operational management objectives, production management identifies production flows and points of waste during the process and integrates lean manufacturing principles to improve work processes.

The company's investments in production for the application of manufacturing systems range from costs involved in layout rearrangement and process flow changes for the acquisition of compact and flexible machines. This investment aims to-under lean principles-visualize the production flow and identify excess production with the consequential accumulation of inventory and storage costs and quality problems (defects) that result in waste and rework. Ultimately, delivery times and the excessive 
movement of people, products, and information are impacted, resulting in wasted time and costs.

One solution that the auto company applies to its production lines involves the grouping of small and flexible machines organized into work or manufacturing cells (U-shaped manufacturing cells) dedicated to the production of a specific product family. In addition to investments made in the shop floor based on lean manufacturing concepts, especially for U-shaped cells workers are heavily involved in production because they are responsible for operating machines and minimizing operation cycle periods, reducing inventory volumes and maximizing the quality of products processed in the cell.

\subsection{Analysis of the manufacturing process}

The process studied in this paper involves a manufacturing cell designed to prevent long lead times.

From the concept of manufacturing through cellular manufacturing, a family of Oil Seals products was identified. The part's family manufacturing processes were then organized to correspond with existing machine tools used on the shop floor. The purpose of the product machine grouping was to form groups of manufacturing processes in which products do not need to move from one cell to another for complete processing.

The operation of the U-shaped cell occurs as workers produce and supervise the fabrication of high-volume production sealing components. Production management is interconnected with an enterprise resource planning (ERP) system that adopts manufacturing execution software (MES). This software is a modular solution and its functionalities can be implemented according to control priorities of the factory floor, as it replaces notes applied manually on the shop floor by collecting data online during production, generating real-time information for manufacturing monitoring, and automating planning and management system reports used by the company.

Before the collaborative operation process is implemented, the manufacturing $U$ shaped cell is characterized as strictly involving manual operation and as involving four workers who take turns performing activities under the three-shift regime, which involves performing 21 hours of work per day to meet monthly production demands. The manufacturing processes and flow of operations that the machine tools perform (injection, machining, inspection, polish/greasing, and assembly) are based on the standard U-shaped layout of this line as shown in Figure 3, and each worker performs the following activities of the production process based on that standard layout:

Tasks performed by worker 1 :

- Load parts into the injection mold of the injection molding machine;

- Load small metallic components into an automatic feeder; and

- Unload injected parts from a mold cavity after the ejection system ejects the part from the mold.

Tasks performed by worker 2 :

- Load and unload parts from the milling machine (remove any burrs from the edges of parts);

- Load and unload parts from the measure machine (to monitor the production process); and 
- Reinspect scrapped parts selected by the measuring machine (monitor quality and remove parts).

Tasks performed by worker 3 :

- Load and unload parts of the assembly machine; and

- Add spiral spring components throughout this process.

Tasks performed by worker 4 :

- Load and unload parts of the polishing/grease machine; load and unload oil seal products at the packing station (packaging goods); and

- Accurately label and stack goods (make products ready for shipment).

All information flow and production data were controlled using MES software.

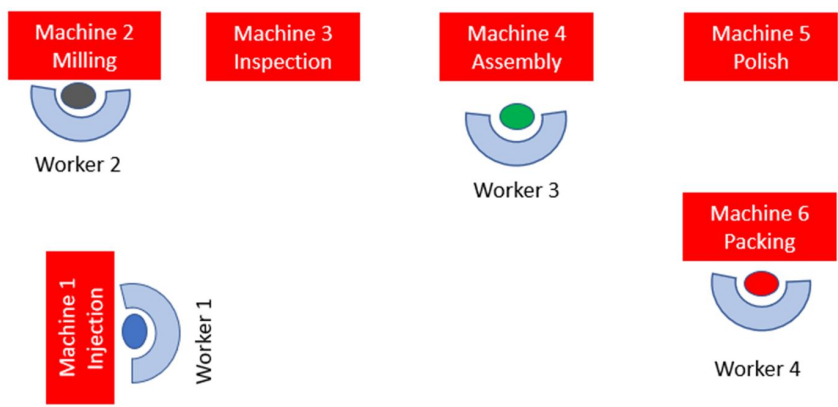

Figure 3. Previous U-shaped manual assembly system.

It should be noted that the U-shaped layout developed for this family of products (see Figure 3) positively impacts the line flow, creating more standardized production steps and positively affecting set-up and product processing time. We also find that the cellular disposition for producing this family of products generates less waste during production because all tools and materials are positioned correctly within the appropriate place. In addition, the layout enhances the visuality of production and teamwork and ultimately helps reveal hidden problems.

In view of this scenario, cobots were adopted to support workers in performing material handling tasks considered by the auto company's engineers as low valueadded operations. The workers were given more time to carry out higher value-added tasks of the manufacturing process.

After the implantation of the collaborative U-shaped manufacturing cell and in the context of Industry 4.0, using model UR-10 cobots of Universal Robots, the cell was characterized as a hybrid manufacturing cell (Lotter, 2012; Krüger et al., 2009). One of the goals of introducing cobots into the U-shaped manufacturing cell was to maintain flexibility in the production of a variety of products. Minor changes to the positioning of machines within the cell have also been made to maintain the same level of material flow and to adapt the reach of the cobots to the correct level of material handling between the machines.

Under the new configuration, the cell now involves one worker and two cobots that work on the same three-shift regime, which involves the following activities:

Tasks performed by cobot \#1: 
- Load parts into the injection mold of the injection molding machine to be molded by the injection unit; and

- Unload injected parts from a mold cavity after the ejection system ejects the part from the mold.

Tasks performed by cobot \#2:

- Load and unload the oil seals product packing station (label packaged goods); and

- Load and unload parts of the assembly machine.

Tasks performed by the worker:

- Load small metallic components into an automatic feeder;

- Reinspect scrapped parts selected by the measuring machine (monitor quality and remove parts);

- Load spiral spring components; and

- Accurately label and stack goods (makes products ready for shipment).

Manufacturing processes and operation flows are based on the layout distribution illustrated in Figure 4. All information flow and production data are controlled using MES software.

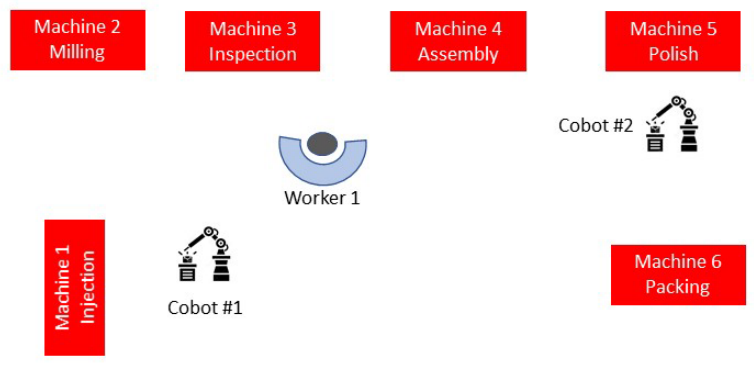

Figure 4. Collaborative U-shaped manufacturing cell.

Under the new layout, cobots can physically interact with workers in a cellular manufacturing environment (Peshkin et al., 2001). The collaborative work cell (Lotter, 2012) shown in Figure 4 uses the attributes of both workers and cobots (Thiemermann, 2004). In the distribution of activities, the cobot performs repetitive movements of less difficulty when handling products of a standard basic structure to load and unload parts from the machine tools (Scholer et al., 2015; Charalambous et al., 2016). Meanwhile, workers can focus on tasks that require the use of more complex cognitive and reasoning skills (Scholer et al., 2015).

The auto company planned to apply this cell design to reduce indirect costs by combining a heavy use of machine tools with the support of cobots that manage products, thus reducing the number of tasks performed by workers.

As is shown in Figure 4, after the incorporation of cobots into the U-shaped manufacturing cell, the machines continued to be located positioned to each other and were dedicated to the production of the same family of parts. This configuration adopting cobots thus provides an efficient flow and supports a high production rate.

To conduct fieldwork, the researchers were granted access to information on the quality system of the surveyed company. Of the various metric options used in the 
industry to evaluate whether a process is efficient, the auto company uses the Overall Equipment Effectiveness (OEE) indicator to calculate the overall efficiency of its equipment. Among the several lean tools proposed in the literature, overall equipment effectiveness (OEE) is a well-known efficiency metric for evaluating the impact of several hidden losses by comparing the actual performance of a piece of equipment with respect to its theoretical potential (Jonsson \& Lesshammar, 1999). The OEE tool is designed to identify losses that reduce equipment effectiveness.

The efficiency with which a manufacturing operation is used is calculated as a percentage metric that represents how strong a company's best practices are based on three productivity variables: availability of equipment for production, the quality of what is produced and performance. According Sonmez et al. (2018) the conventional OEE is determined by multiplying three components related to a piece of equipment, as presented from Equations 1 to 4 :

$O E E=$ availability $x$ performance $x$ quality

where:

$$
\begin{aligned}
& \text { Availability }=\frac{\text { operating time }}{\text { planned operating time }}=\frac{T p-T L r}{T p} \\
& \text { Performance }=\frac{\text { net operating time }}{\text { operatiing time }}=\frac{S r}{S p} \\
& \text { Quality }=\frac{\text { valuableoperating time }}{\text { net operating time }} \frac{P c}{P a}
\end{aligned}
$$

To evaluate OEE, the company adopts the World Class OEE index as a benchmark (Sonmez et al., 2018). The most efficient factories have an index of $85 \%$, while average companies have an index of $60 \%$ (Nagdiya \& Bhabhor, 2013).

According to data provided by the company, in 2016, the monthly average of the manual cell efficiency indicator value was $72 \%$. After adopted the hybrid manufacturing cell, the reliability indicator and mean monthly performance for 2017 of $72 \%$ increased to $92.6 \%$.

Graph 1 shows the indicator obtained for 2016 with the manual workstation shown in Figure 3 presented as a reference. OEE reached an average value of $72 \%$ or lower than the reference World Class OEE. This value was influenced by machine tools damages and setup time and by a lack of materials.

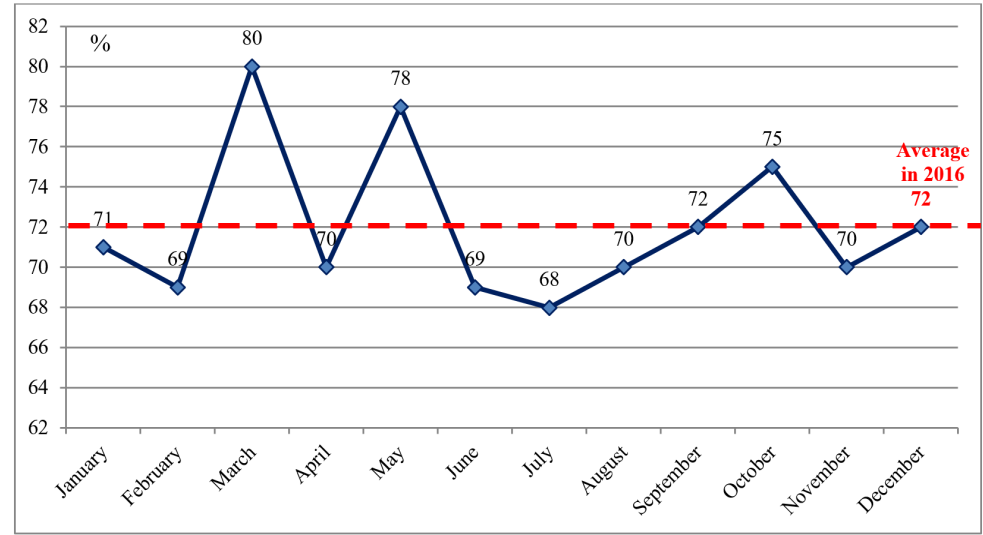

Graph 1. Manual work performance (OEE) in 2016. 
To measure the manufacturing cell's efficiency after the introduction of the collaborative workstation in the first half of 2017, the measurement of the scenario related to the manual workstation was considered to understand where the company was positioned.

Graph 2 presents the OEE indicator measured after the application of the collaborative U-shaped manufacturing cell based on the layout arrangement shown in Figure 4. OEE, which is related to a company's quality management systems, was monitored for 21 days in September 2017. During this follow-up period, the cell achieved an average efficiency level of $92.6 \%$. For this measurement we considered the same criteria to map priorities while measuring the manual workstation.

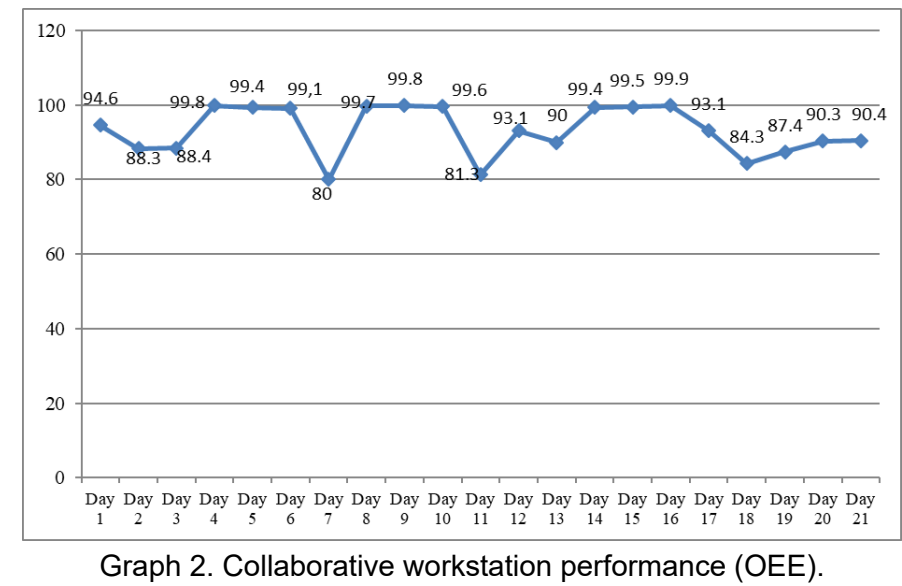

\section{Discussion of results}

We thus find that the U-shaped cell configuration applying the collaborative operation process is more reliable (Hayes \& Wheelwright, 1984; Slack \& Lewis, 2017) and performs better (Maylor et al. 2015) in meeting the same level of monthly production demand as the manual process.

The degree of adherence to competitive priorities when using a hybrid manufacturing cell (Lotter, 2012) does not apply in its entirety to all competitive priorities (Skinner, 1969 and Wheelwright, 1984).

1. Costs: total adherence to the hybrid process is achieved, as a reduction in labor costs is obtained in addition to an increase in efficiency from 21 to 24 hours/day;

2. Quality: partial adherence is observed when adopting a hybrid cell for manufacturing, as improvements in quality due to levels of precision and repeatability provided by a cobot are not possible through manual assembly. However, as the use of collaborative robots for high production volumes remains limited, manual labor prevails in operations cases for this type of demand;

3. Flexibility: partial adherence to the hybrid process is observed because cobots are identified as being very flexible in managing operations involving simple movements. However, in the case of more complex movements that cannot be performed by cobot arms, manual work is more flexible; 
4. Reliability: reliability shows total adherence to the hybrid process because due to manufacturing deadlines and deadlines created by changes in demand, cobots can quickly and effectively reinstall and produce a new product to meet market demand.

These results indicate that cobots can strengthen a company's competitive capabilities related to cost and delivery. However, it is important to recognize that cost reductions-while an important competitive priority-should be followed with enhancements of other competitive capabilities (e.g., quality in high volumes, flexibility, and innovativeness).

These results are akin to those given by Thürer et al. (2013), according to whom competitive manufacturing capabilities do not appear to be completely deliberate or aligned with competitive priorities. However, our results on the adoption of cobots in a collaborative workstation corroborate those of Slack \& Lewis (2017) on the role of operations management in the ability to master new process technologies, achieve flexible production, and reduce costs through the use of improvement and optimization programs.

We also observe an adherence to hybrid assembly processes described by Lotter (2012) and Heilala \& Voho (2001) in manual and automated processes (number of variants, batch size, flexibility, and productivity).

The classic (cost, quality, flexibility, and reliability) and most modern competitive priority of innovation can support operations management in meeting its objectives and in creating a competitive advantage for a company according to process technologies applied during production (Jain et al., 2014). From competitive priorities, operations management fulfills its objectives in supporting corporate strategies (Hayes \& Wheelwright, 1984). However, new developments for the application of collaborative robots in the industry with a view to reducing costs and enhancing quality, flexibility, and reliability are not yet a part of the operations strategies of most companies and of Brazilian companies in particular. Perhaps this lack of strategic vision is the result of conjunctural economic conditions that leave the environment more uncertain for investments in robotics.

From an ergonomic perspective, the auto company studied has through ergonomic studies identified the following technical issues, and related tasks were allocated to robots of the collaborative U-shaped manufacturing cell:

- Worker body exposure to hot temperatures from the injection molding machine; and

- Workers performing the same series of motions continually for an extended period of time and in positions that place stress on the body.

The goal was to enhance workers' performance to limit hazards and injuries.

Finally, the results indicate that the implementation of a hybrid cell supports the four features of the operations strategy approach (strategic intent, focus, adequacy, and resource configuration) proposed by Maylor et al. (2015).

\section{Conclusion}

Broadly, this paper offers insight into how a company can develop a model that structures and combines competitive capabilities and competitive priorities and that 
adopts technologies used in Industry 4.0 with a managerial weighting to determine features relevant to achieving the best degree of manufacturing automation.

The paper also offers reflections on the impact of competitive priorities on operations strategies in the context of Industry 4.0 when including collaborative robots in U-shaped cells. The results show that a hybrid cell can fully adhere to competitive priorities of cost and reliability while partially adhering to quality and flexibility requirements.

Some limitations encountered during our field research specifically related to the strategic data used given their classified nature prevented us from conducting a more robust analysis of the operation strategy formulation process. While this work focused on one case study, future research in this field may focus on several different small cells of the overall process and on the comparative analysis of results for these cells.

Although productivity gains in other countries are known and especially in developed countries, this study is also limited in that it does not analyze the costs and benefits, quality levels, and performance of diverse cobots and of their respective manufacturers. Thus, future related research on emerging countries will prove relevant to company decision making. Finally, as in most cases, automation decision making occurs according to the personal experiences of engineers and managers, and future work on the returns on investment of a collaborative work cell is thus recommended.

\section{References}

Beach, R., Muhlemann, A., Price, D., Paterson, A., \& Sharp, J. (2000). Manufacturing operations and strategic flexibility: survey and cases. International Journal of Operations \& Production Management, 20(1), 7-30. http://dx.doi.org/10.1108/01443570010301056.

Bloss R. (2016). Industrial robot: collaborative robots are rapidly providing major improvements in productivity, safety, programing ease, portability and cost while addressing many new applications. Industrial Robot, an International Journal, 43/5, 463-468.

Boyer, K. K., \& McDermott, C. (1999). Strategic consensus in operations strategy. Journal of Operations Management, 17(3), 289-305. http://dx.doi.org/10.1016/S0272-6963(98)00042-4.

Brown, S., \& Bessant, J. (2003). The manufacturing strategy-capabilities links in mass customisation and agile manufacturing - an exploratory study. International Journal of Operations \& Production Management, 23(7), 707-730.

Charalambous, G., Fletcher, S., \& Webb, P. (2016). The development of a scale to evaluate trust in industrial human-robot collaboration. International Journal of Social Robotics, 8(2), 193-209. http://dx.doi.org/10.1007/s12369-015-0333-8.

D'Aveni, R. (1994). Hyper-competition: managing the dynamics of strategic maneuvering. New York: Free Press.

Díaz-Garrido, E., Martín-Peña, M. L., \& Sánchez-López, J. M. (2011). Competitive priorities in operations: development of an indicator of strategic position. CIRP Journal of Manufacturing Science and Technology, 4(1), 118-125. http://dx.doi.org/10.1016/j.cirpj.2011.02.004.

Drath, R., \& Horch, A. (2014). Industrie 4.0: hit or hype? IEEE Industrial Electronics Magazine, 8(2), 56-58. http://dx.doi.org/10.1109/MIE.2014.2312079.

Eisenhardt, K. M. (1989). Building theories from case study research. The Academy of Management Review, 14(4), 532-550.

Eisenhardt, K. M., \& Bourgeois, L. J., 3rd. (1988). Politics of strategic decision making in highvelocity environments: toward a midrange theory. Academy of Management Journal, 31(4), 737-770. 
Fatorachian, H., \& Kazemi, H. (2018). A critical investigation of Industry 4.0 in manufacturing: theoretical operationalization framework. Production Planning and Control, 29(8), 1-12. http://dx.doi.org/10.1080/09537287.2018.1424960.

Gagnon, S. (1999). Resource-based competition and the new operations strategy. International Journal of Operations \& Production Management, 19(2), 125-138. http://dx.doi.org/10.1108/01443579910247392.

Groover, M. P. (2017). Automation, production systems, and computer-integrated manufacturing (4th ed., 809 p.). Harlow: Editora Prentice Hall, Inc., Pearson Education.

Harper, C., \& Virk, G. (2010). Towards the development of international safety standards for human robot interaction. springer science \& business media. International Journal of Social Robotics, 2(3), 229-234. http://dx.doi.org/10.1007/s12369-010-0051-1.

Hayes, R. H., \& Wheelwright, S. C. (1984). Restoring our competitive edge: competing through manufacturing. Hoboken: Wiley.

Heilala, J., \& Voho, P. (2001). Modular reconfigurable flexible final assembly systems. Assembly Automation, 21(1), 20-30. http://dx.doi.org/10.1108/01445150110381646.

Hermann, M., Pentek, T., \& Otto, B. (2016). Design principles for industrie 4.0 scenarios. In: Proceedings of the 49th Hawaii International Conference on System Sciences (HICSS) (pp. 3928-3937). USA: IEEE.

Hill, T. (2000). Manufacturing strategy. Londres: Palgrave. http://dx.doi.org/10.1007/978-1-34914018-3.

Ibarguren, A., Maurtua, I., Pérez, M. A., \& Sierra, B. (2015). Multiple target tracking based on particle filtering for safety in industrial robotic cells. Robotics and Autonomous Systems, 72, 105-113. http://dx.doi.org/10.1016/j.robot.2015.05.004.

Jain, B., Adil, G. K., \& Ananthakumar, U. (2014). Development of questionnaire to assess manufacturing capability along different decision areas. International Journal of Advanced Manufacturing Technology, 71(9-12), 2091-2105. http://dx.doi.org/10.1007/s00170-0135589-2.

Jitpaiboon, T., Gu, Q., \& Truong, D. (2016). Evolution of competitive priorities towards performance improvement: a meta-analysis. International Journal of Production Research, 54(24), 7400-7420. http://dx.doi.org/10.1080/00207543.2016.1190878.

Jonsson, P., \& Lesshammar, M. (1999). Evaluation and improvement of manufacturing performance measurement systems - the role of OEE. International Journal of Operations \& Production Management, 19(1), 55-78. http://dx.doi.org/10.1108/01443579910244223.

Kim, J. S., \& Arnold, P. (1996). Operationalizing manufacturing strategy: an exploratory study of constructs and linkage. International Journal of Operations \& Production Management, 16(12), 45-73. http://dx.doi.org/10.1108/01443579610151751.

Kim, Y. H., Sting, F. J., \& Loch, C. H. (2014). Top-down, bottom-up, or both? Toward an integrative perspective on operations strategy formation. Journal of Operations Management, 32(7-8), 462-474. http://dx.doi.org/10.1016/j.jom.2014.09.005.

Kootbally, Z. (2016). Industrial robot capability models for agile manufacturing. Industrial Robot. International Journal (Toronto, Ont.), 43(5), 481-494.

Krüger, J., Lien, T. K., \& Verl, A. (2009). Cooperation of human and machines in assembly lines. CIRP Annals - Manufacturing Technology, 58, 628-646. http://dx.doi.org/10.1016/j.cirp.2009.09.009.

Lekurwale, R. R., Akarte, M. M., \& Raut, D. N. (2015). Framework to evaluate manufacturing capability using analytical hierarchy process. International Journal of Advanced Manufacturing Technology, 76(1-4), 565-576. http://dx.doi.org/10.1007/s00170-014-6284-7.

Lien, T. K., \& Rasch, F. O. (2001). Hybrid automatic-manual assembly systems. CIRP AnnalsManufacturing Technology, 50(1), 21-24. http://dx.doi.org/10.1016/S0007-8506(07)62062-9. 
Lin, Y.-H., \& Tseng, M.-L. (2016). Assessing the competitive priorities within sustainable supply chain management under uncertainty. Journal of Cleaner Production, 112, 2133-2144. http://dx.doi.org/10.1016/j.jclepro.2014.07.012.

Lotter, E. (2012). Montage in der industriellen produktion (2nd ed., 501 p.). Berlin. Editora Springer. http://dx.doi.org/10.1007/978-3-642-29061-9.

Maylor, H., Turner, N., \& Murray-Webster, R. (2015). "It worked for manufacturing...!": operations strategy in project-based operations. International Journal of Project Management, 33(1), 103-115. http://dx.doi.org/10.1016/j.ijproman.2014.03.009.

Nagdiya, M., \& Bhabhor, K. (2013). Performance analysis using OEE. International Journal of Schientific Research \& Development, 1(4), 2321-0613.

Ore, F., Vemula, B. R., Hanson, L., \& Wiktorsson, M. (2016). Application of simulation software for workstation optimisation. Procedia CIRP, 44, 181-186. http://dx.doi.org/10.1016/j.procir.2016.02.002.

Peshkin, M. A., Colgate, J. E., Wannasuphoprasit, W., Moore, C. A., Gillespie, R. B., \& Akella, P. (2001). Cobot architecture. IEEE Transactions on Robotics and Automation, 17(4), 377390. http://dx.doi.org/10.1109/70.954751.

Qin, J., Liu, Y., \& Grosvenor, R. (2016). A categorical framework of manufacturing for industry 4.0 and beyond. Procedia CIRP, 52, 173-178. http://dx.doi.org/10.1016/j.procir.2016.08.005.

Scholer, M., Vette, M., \& Rainer, M. (2015). A lightweight robot system designed for the optimisation of an automotive end-off line process station. Industrial Robot. International Journal (Toronto, Ont.), 42(4), 296-305.

Schroeder, D. M., Congden, S. W., \& Gopinath, C. (1995). Linking competitive strategy and manufacturing process technology. Journal of Management Studies, 32(2), 163-189. http://dx.doi.org/10.1111/j.1467-6486.1995.tb00339.x.

Skinner, W. (1969). Manufacturing - missing link in corporate strategy. Brighton: Harvard Business Review.

Skinner, W. (1974). The focused factory (Vol. 52, pp. 113-121). Brighton: Harvard Business Review.

Slack, N., \& Lewis, M. (2017). Estratégia de operações (492 p.). Porto Alegre. Editora Brookman.

Sonmez, V., Testik, M. C., \& Testik, O. M. (2018). Overall equipment effectiveness when production speeds and stoppage durations are uncertain. International Journal of Advanced Manufacturing Technology, 95(1-4), 121-130. http://dx.doi.org/10.1007/s00170017-1170-8.

Su, S. F., Rudas, I. J., Zurada, J. M., Er, M. J., Chou, J.-H., \& Kwon, D. (2017). Industry 4.0: a special section in IEEE access. IEEE Access : Practical Innovations, Open Solutions, 5 , 12257-12261. http://dx.doi.org/10.1109/ACCESS.2017.2704758.

Takata, S., \& Hirano, T. (2011). Human and robot allocation method for hybrid assembly systems. CIRP Annals-Manufacturing Technology, 60(1), 9-12. http://dx.doi.org/10.1016/j.cirp.2011.03.128.

Tan, K. C., Kannan, V. R., \& Narasimhan, R. (2007). The impact of operations capability on firm performance. International Journal of Production Research, 45(21), 5135-5156. http://dx.doi.org/10.1080/00207540600871269.

Thiemermann, S. (2004). Direkte Mensch-Roboter-Kooperation in der Kleinteilemontage mit einem SCARA-Roboter (123 p.). Stuttgart: University of Stuttgart.

Thürer, M., Godinho, M., Fo., Stevenson, M., \& Fredendall, L. D. (2013). Competitive priorities of small manufacturers in Brazil. Industrial Management \& Data Systems, 113(6), 856-874. http://dx.doi.org/10.1108/IMDS-01-2013-0049. 
Tsarouchi, P., Makris, S., \& Chryssolouris, G. (2016). Human-robot interaction review and challenges on task planning and programming. International Journal of Computer Integrated Manufacturing, 29(8), 916-931. http://dx.doi.org/10.1080/0951192X.2015.1130251.

Vasic, M., \& Billard, A. (2013). Safety issues in human-robot interactions. In Proceedings of the IEEE International Conference on Robotics and Automation (ICRA) (pp. 197-204). USA: IEEE. http://dx.doi.org/10.1109/ICRA.2013.6630576.

Voss, C., Tsikriktsis, N., \& Frohlich, M. (2002). Case research in operations management. International Journal of Operations \& Production Management, 22(2), 195-219. http://dx.doi.org/10.1108/01443570210414329.

Wang, L. (2015). Collaborative robot monitoring and control for enhanced sustainability. International Journal of Advanced Manufacturing Technology, 81(9-12), 1433-1445. http://dx.doi.org/10.1007/s00170-013-4864-6.

Wathen, S. (1995). Manufacturing strategy in business units: an analysis of production process focus and performance. International Journal of Operations \& Production Management, 15(8), 4-13. http://dx.doi.org/10.1108/01443579510094053.

Wheel Wright, S. C. (1984). Manufacturing strategy: defining the missing link. Strategic Management Journal, 5(1), 77-91. https://doi.org/10.1002/smj.4250050106.

Yin, R. K. (2013). Case study research: design and methods (5th ed.). California: Sage Publications. 
Appendix A. Interview script.

\begin{tabular}{|c|c|}
\hline \multirow{12}{*}{$\begin{array}{l}\text { Perceptions of top } \\
\text { managers on the } \\
\text { adopted strategy and } \\
\text { on its relationships with } \\
\text { the collaborative robots }\end{array}$} & $\begin{array}{l}\text { What objectives of the corporate strategy are influenced by the } \\
\text { operational strategy (or vice versa)? }\end{array}$ \\
\hline & $\begin{array}{l}\text { How can the cobot support the corporate strategy of the operational } \\
\text { strategy? }\end{array}$ \\
\hline & $\begin{array}{l}\text { Do cost differences between conventional robots and cobots justify the } \\
\text { implementation of cobots? }\end{array}$ \\
\hline & $\begin{array}{l}\text { What are the impacts of cobot implementation related to the following } \\
\text { aspects of operations management: cost, flexibility, quality and } \\
\text { dependability? }\end{array}$ \\
\hline & $\begin{array}{l}\text { How did cobot implementation affect the objectives of the corporate } \\
\text { strategy considering impacts on costs, quality, flexibility and } \\
\text { dependability? }\end{array}$ \\
\hline & $\begin{array}{l}\text { Do you think that perceptions of the costs, flexibility and quality of the } \\
\text { manufacturing process justify cobot investment? }\end{array}$ \\
\hline & $\begin{array}{l}\text { Did you find any operational capabilities to improve as a result of } \\
\text { cobot implementation? }\end{array}$ \\
\hline & How was flexibility affected by cobot implementation? \\
\hline & $\begin{array}{l}\text { Any there any ways in which you think that the cobot has enhanced } \\
\text { operational capabilities? }\end{array}$ \\
\hline & To what degree have the workers accepted the cobot's introduction? \\
\hline & $\begin{array}{l}\text { How homologated were safety issues during the cobot's } \\
\text { implementation? }\end{array}$ \\
\hline & $\begin{array}{l}\text { Do you have any recommendations on ways to structure Brazilian } \\
\text { regulations concerning the large-scale use of cobots? }\end{array}$ \\
\hline \multicolumn{2}{|c|}{ Classical competitive priorities/capabilities (Hayes \& Wheelwright, 1984) } \\
\hline \multirow{4}{*}{$\begin{array}{l}\text { What competitive } \\
\text { capabilities/priorities } \\
\text { impact and/or are } \\
\text { impacted by cobot } \\
\text { implementation? }\end{array}$} & Quality \\
\hline & Dependability \\
\hline & Cost \\
\hline & Flexibility \\
\hline Quality & Dimensions \\
\hline \multirow{7}{*}{$\begin{array}{l}\text { 14. Which quality } \\
\text { dimensions impact } \\
\text { and/or are impacted by } \\
\text { cobot implementation? }\end{array}$} & Performance-major operational characteristics \\
\hline & Resources-extras/optional \\
\hline & Reliability-probability of failure \\
\hline & Conformity-accordance with specifications \\
\hline & Maintenance facilities \\
\hline & Perceived quality-reputation \\
\hline & Value for money \\
\hline Dependability & Dimensions \\
\hline \multirow{3}{*}{$\begin{array}{l}\text { 15. Which } \\
\text { dependability } \\
\text { dimensions impact } \\
\text { and/or are impacted by } \\
\text { cobot implementation? }\end{array}$} & Lead time \\
\hline & Delivery time \\
\hline & Frequency of delivery \\
\hline Cost & Dimensions \\
\hline \multirow{6}{*}{$\begin{array}{l}\text { 16. Which cost } \\
\text { dimensions impact } \\
\text { and/or are impacted by } \\
\text { cobot implementation? }\end{array}$} & Manufacturing costs \\
\hline & Added value \\
\hline & Sale price \\
\hline & Operational cost-cost of keeping the product in working order \\
\hline & Service cost-maintenance cost \\
\hline & Profit \\
\hline Flexibility & Dimensions \\
\hline
\end{tabular}


Perceptions of top managers on the adopted strategy and on its relationships with the collaborative robots

What objectives of the corporate strategy are influenced by the operational strategy (or vice versa)?

How can the cobot support the corporate strategy of the operational strategy?

Do cost differences between conventional robots and cobots justify the implementation of cobots?

What are the impacts of cobot implementation related to the following aspects of operations management: cost, flexibility, quality and dependability?

How did cobot implementation affect the objectives of the corporate strategy considering impacts on costs, quality, flexibility and dependability?

Do you think that perceptions of the costs, flexibility and quality of the manufacturing process justify cobot investment?

Did you find any operational capabilities to improve as a result of cobot implementation?

How was flexibility affected by cobot implementation?

Any there any ways in which you think that the cobot has enhanced operational capabilities?

To what degree have the workers accepted the cobot's introduction?

How homologated were safety issues during the cobot's implementation?

Do you have any recommendations on ways to structure Brazilian regulations concerning the large-scale use of cobots?

Flexibility in managing new products

Capacity to change predetermined deadlines

Which flexibility Capacity to accept different production methods

dimensions impact and/or are impacted by cobot implementation?

Capacity to accept different production volumes

Capacity to create new products to manage product changes

Reliability with which an order (and its volume) will be delivered on time

What other competitive Services capabilities/priorities impact and/or are impacted by cobot Manufacturing technology Innovation

implementation? 